\title{
International Unit per Milligram
}

National Cancer Institute

\section{Source}

National Cancer Institute. International Unit per Milligram. NCI Thesaurus. Code C67380.

A unit of measure of quantity of substance per unit mass, expressed in terms of

International Units per milligram. (CDISC) 